\title{
European integration studies and the European Union's Eastern gaze
}

\begin{abstract}
European integration studies has recently seen the first signs of a belated critical turn. Whilst new approaches have started to challenge the way the European Union is conventionally studied, they are yet to investigate in detail the relationship between the academic field and its primary object of study. This article draws on work in critical geopolitics to explore one of the interfaces of academic knowledge on European integration and the world of policy: the Jean Monnet Programme. In highlighting the scheme's role in the EU's Eastern geopolitics, it argues that European integration studies resembles other forms of area studies, such as Cold War era Sovietology. This comparison elucidates both the field's longstanding resilience to critical theory and its inability to anticipate the recent crisis of the European project.
\end{abstract}

\section{Introduction ${ }^{1}$}

Uniting a variety of disciplinary influences, European integration studies (short: European Studies, sometimes EU Studies) tends to self-identify as the study of the European Union's institutions. Whilst research on European integration has long developed sophisticated analyses of bureaucratic decision-making and institutional evolution, debates in European Studies have often been limited to the types of problems that concern Brussels practitioners, such as the coherence, convergence, effectiveness and success of policies. More often than not, European integration studies tends to investigate 'the extent to which integration has occurred, or the likelihood that it will occur in the future'.2 Such teleological readings of EU politics are often accompanied by an implicit Europhile undertone that reproduces the discourse of Brussels institutions and think tanks. In a biting critique of European Studies' inability to account for the Eurozone crisis, Magnus Ryner has recently spoken of a 'European integration orthodoxy' in the pages of this journal to capture this combination of instrumentality, empiricism and liberalism that dominates much of the field. ${ }^{3}$

Interestingly, this problem-solving approach has not been limited to research and European universities have often promoted European Studies as a vocational degree. Perhaps as a consequence, the field has tended to attract a career-oriented student body that has eagerly targeted a number of EU-funded campuses and bureaucratic training centres such as the College of Europe (Bruges and Natolin campuses), the European University Institute (Florence), the European Institute of Public Administration (Maastricht), the Academy of European Law (Trier) and the International Centre for European Training (Nice), all of which have been financed to pursue 'an aim of European interest'. ${ }^{4}$ Selling itself as 'the most genuinely "European" of

\footnotetext{
${ }^{1}$ I would like to thank audiences at the $20^{\text {th }}$ International Conference of Europeanists in Amsterdam, the $8^{\text {th }}$ Pan-European Conference by the Standing Group on International Relations and King's College London's Jean Monnet Centre of Excellence for their input. I am particularly grateful for conversations with Ian Bruff, Rene Gabriels, Gonzalo Pozo, Ludek Stavihoha and Virginie Mamadouh on the topic of European integration Studies.

2 Chris Rumford and Philomena Murray, 'Do we need a core curriculum in European Union studies?', European Political Sciences 3, no. 1 (2003): 85-92, 86.

${ }^{3}$ Magnus Ryner, 'Financial crisis, orthodoxy and heterodoxy in the production of knowledge about the EU', Millennium: Journal of International Studies 40(3) (2012): 647-673, 650.

4 European Commission, 'Lifelong learning programme: Guide 2013 Part IIa', available at http://eacea.ec.europa.eu/llp/funding/2013/documents/jean_monnet_ka1 (2013) [accessed 20 December 2013], 2.
} 
all the university institutes', the College of Europe promises its prospective students a professional environment and interaction with senior EU officials and think-tankers. ${ }^{5}$ Similarly, Maastricht University guarantees its postgraduates 'practical assignments derived from the practice of European public affairs, whereby in small international teams, under strict and tight deadlines, students simulate the professional world as much as possible'. ${ }^{6}$

In emphasising its instrumental and problem-solving objectives in research and teaching, European Studies has been strangely resilient to theoretical developments that have swept through other parts of the Social Sciences. ${ }^{7}$ Whilst most cognate disciplines have gone through 'critical' and 'self-reflective' turns over the last two decades, the study of European integration has only just witnessed the early stages of a deferred critical turn, which has seen the emergence of chapters on critical European Studies in textbooks ${ }^{8}$ and a 2013 critical European Studies book series with Routledge. Interestingly, approaches that challenge the way European integration is conventionally studied have not always appeared at the heart of European Studies but in neighbouring disciplines and sub-disciplines, such as International Relations, International Political Economy, International Political Sociology or Political Geography. There is no space here to discuss these fields in detail, but it is worth mentioning that this body of work no longer just includes neo-Gramscian ${ }^{9}$ and discourse approaches, ${ }^{10}$ but increasingly studies of governmentality ${ }^{11}$ and work inspired by critical geopolitics. ${ }^{12}$ Yet, whilst this scholarship has provided a number of alternative entries into the study of European integration, it is still to reflect in depth on the particular mechanics of knowledge production characteristic of European Studies.

Perhaps unsurprisingly, the existence of an intimate relationship between policy and the academy has not slipped the attention of some of the field's theorists. Debates have long addressed the related question as to whether European Studies' theoretical evolution, from approaches such as 'neo-functionalism' to concepts like 'Europeanisation', is driven by theoretical innovations within the academy itself or by events in EU politics. ${ }^{13}$ Moreover, scholars have in the past noted the importance of

${ }^{5}$ College of Europe, 'College of Europe brochure', available at https://www.coleurope.eu/brochure (2013) [accessed 9 February 2014], 3, 18.

6 Maastricht University, 'Master's Programme: European Public Affairs', available at http://www.maastrichtuniversity.nl/web/Faculties/FASoS/TargetGroups/ProspectiveStudents/MastersPr ogrammes/EuropeanPublicAffairs.htm (2014) [accessed 5 February 2014].

7 Alan Cafruny and Magnus Ryner, 'The study of European integration in the neoliberal era', in A ruined fortress? Neoliberal hegemony and transformation in Europe, eds Alan Cafruny and Magnus Ryner (Lanham: Rowman and Littlefields, 2003): 1-13, 1.

8 Antje Wiener and Thomas Diez, European integration theory (Oxford: Oxford University Press, 2009); Knud Erik Jørgensen, Mark Pollack and Ben Rosamond, The Sage Handbook on European Union Politics (London: Sage, 2007).

9 Andreas Bieler, 'The struggle over EU enlargement: a historical materialist analysis of European integration', European Journal of Public Policy 9, no. 4 (2002): 595-597.; Bastiaan van Apeldoorn, Henk Overbeek and Magnus Ryner, 'Theories of European integration: a critique', in A ruined fortress? Neoliberal hegemony and transformation in Europe, eds Alan Cafruny and Magnus Ryner (Lanham: Rowman and Littlefield, 2003): 17-45.; Chris Rumford, The SAGE Handbook of European Studies (London: Sage, 2009).

10 Thomas Diez, 'Europe as a Discursive Battleground: Discourse Analysis and European Integration Studies', Cooperation and Conflict 36, no. 1 (2001): 5-38; David Howarth and Jacob Torfing, Discourse Theory in European Politics: Identity, Policy and Governance (New York: Palgrave, 2005).

11 Michael Merlingen, 'From Governance to Governmentality in CSDP: Towards a Foucauldian Research Agenda', Journal of Common Market Studies 49, no. 1 (2011): 149-169.; Andrew Neal, 'Securitization and risk at the EU border: the origins of FRONTEX', Journal of Common Market Studies 47, no. 2 (2009): 333-356.; William Walters and Jens Henrik Haahr, Governing Europe: Discourse, governmentality and European integration (London: Routledge, 2005).

12 Pami Aalto, 'A Geopolitical Subject in the Making? EU, Russia and the Kaliningrad Question', Geopolitics, 7, no. 3 (2002): 143-74.; Luiza Bialasiewicz, Europe in the world: EU geopolitics and the transformation of European space (Aldershot: Ashgate, 2011).; Merje Kuus, Geopolitics reframed: Security and identity in Europe's Eastern enlargement (Basingstoke: Palgrave, 2007).

13 Ben Rosamond, Theories of European integration (Basingstoke: Palgrave, 2000), 194.; Ben Rosamond, 
understanding their own implication in the study of Europe ${ }^{14}$ and have pointed out the 'under-researched relationship between the object of study (EU politics) and the way we as scholars seek to interpret, analyse and describe it'.15 Perhaps the most telling formulation comes from Craig Calhoun who in 2003 observed that European Studies was not just the product of an academic interest in the European Union but 'an ideological-pedagogical project' that had promoted 'a European self-understanding supportive of the EU'.16 The point of this article then is to push these arguments further and inquire into the field's own involvement in the very process it sets out to study.

Examinations of the policy-academy nexus in European Studies could tackle a number of areas, from the funding of EU campuses and the promotion of policyrelevance in academic literature to the subjectivities of students and academics. This article takes as its focus the Jean Monnet Programme, the European Union's funding scheme for Professorships, modules and research centres in European integration studies. Reflection on the history and spatial politics of this scheme brings to light its involvement in the policies of the European Union. This complicity is particularly visible in the Union's post-Cold War Eastern geopolitics, which has been dominated by the dual policies of 'enlargement' and 'neighbourhood'. Whilst the European Union's bold enlargement to parts of the former Soviet bloc (the Czech Republic, Estonia, Hungary, Latvia, Lithuania, Poland, Slovakia and Slovenia in 2004, Bulgaria and Romania in 2007 and Croatia in 2013) was highly visible in old member states, the European Neighbourhood Policy is a stealthier and less ambitious political agenda. Designed in 2004 to deal with the states that lie beyond the enlarged EU's Eastern and Southern borders, it is modelled on enlargement but lacks the promise of EU membership. Nevertheless, both enlargement and neighbourhood have forwarded a transformative agenda of value transfer and conditionality, traces of which can be found in the Jean Monnet Programme also. In making this point, the article draws on work in critical geopolitics, which has long produced the type of self-reflection that is only nascent in European Studies, research that has unearthed the intimate involvement of academic writing with practices of statecraft.

The article proceeds to outline conceptual work that has approached the European Union as a geopolitical entity in order to situate the question of European integration studies and the Jean Monnet Programme within the dual policies of enlargement and neighbourhood. Subsequently, it provides an overview of the Jean Monnet Programme and reveals how the funding scheme has been a crucial and openly acknowledged policy-tool in the European Union's designs for Eastern Europe. It zooms in on recent trends in the geographical distribution of funds, key public intellectuals and the policy discourses that surround the programme. The article then reads these findings through debates on the nature and function of area studies and tentatively explores some of the epistemological overlaps between European Studies and one particularly problematic manifestation of area studies: Cold War era Sovietology. It thereby suggests, contrary to Helen Wallace, that European Studies may never have left the 'backwater of area studies'.17 By exploring European integration studies as one of

'European integration and the social sciences of EU studies: the disciplinary politics of a subfield', International Affairs 83, no. 1 (2007): 231-252.; Thomas Diez and Antje Wiener, 'Introducing the mosaic of integration theory', in European integration theory eds Antje Wiener and Thomas Diez (Oxford: Oxford University Press, 2009): 1-22, 14.

14 Ian Manners, 'Europaian Studies 1', Journal of Contemporary European Studies, 11, no. 1 (2003): 67-83, 80.

15 Ben Rosamond, 'The political sciences of European integration: disciplinary history and EU studies', in The Sage Handbook on European Union Politics, eds Knud Erik Jørgensen, Mark Pollack and Ben Rosamond (London: Sage, 2007): 7-30, 25.

${ }^{16}$ Craig Calhoun, 'European Studies: always already there and still in formation', Comparative European Politics 1, no. 1 (2003): 5-20, 13.

17 Helen Wallace, 'Studying Contemporary Europe', British Journal of Politics and International Relations 2, no. 1: (2000) 95-113, 95. 
the European Union's softest of geopolitical powers, the article helps to reframe the question as to why European Studies was so badly prepared for the Eurozone crisis as one of academic identity.

\section{The European Union through critical geopolitical eyes}

Explorations of European integration through the prism of geopolitics do not come naturally to European Studies and the two have rarely been thought together outside of Political Geography. ${ }^{18}$ After all, Brussels has not acquired the traditional insignias of geopolitical power, such as a centralised and decisive foreign policy or a significant standing army. Moreover, since the European Union has in the past distanced itself from the kind of balance of power considerations that are characteristic of so-called great powers, the Union's policies would not seem to be informed by a coherent geopolitical tradition. ${ }^{19}$ The European Union's enlargement is thereby read as a post-sovereign and post-modern acquisition of space rather than geopolitical expansion. ${ }^{20}$ As a consequence, the European Union is conventionally thought of as precisely the project that managed to overcome the perilous gaze of geopolitics and its territorially trapped thinking. ${ }^{21}$

Despite these reservations, research in Political Geography has since the early 2000 s interrogated the spatial politics of European integration. Fuelled by an understanding of Europe as a simultaneously geographical and political notion, a continent and a polity, it has produced work precisely on that which should not be, the geopolitics of the European Union. Given this taboo around geopolitics, it is important to keep in mind the stealthy ways in which geopolitics is sometimes evoked and often deliberately avoided in Brussels. ${ }^{22}$ To approach the EU geopolitically is to remember that the European Coal and Steel Community was born out of geopolitical considerations centred on the balance of power, the fear of war and the role of natural resources. ${ }^{23}$ Furthermore, it is to acknowledge that the Union has been actively engaged in the bordering and ordering of European space, especially since the end of the Cold War. In approaching the European Union as only seemingly post-geopolitical, Political Geographers have made a number of key advances, often under the umbrella of 'critical geopolitics'. ${ }^{24}$ They have examined geopolitical narratives, practices and mappings that have circulated in Brussels policy and think tank circles, 25 the production of borders and

\footnotetext{
18 For two notable exceptions see Thomas Diez, 'Europe's others and the return of geopolitics', Cambridge Review of International Affairs, 17, no. 2 (2004): 319-335.; James Rogers, 'From "civilian power" to "global power": explicating the European Union's "grand strategy" through discourse theory', Journal of Common Market Studies 47, no. 4 (2009): 831-862.

19 Council of the European Union, 'Solana: US, EU must embrace shift to East', available at http://www.consilium.europa.eu/uedocs/cms data/docs/pressdata/en/pressReview/110380.pdf (2009) [accessed 14 December 2013].

${ }^{20}$ Jan Zielonka, Europe as empire: the nature of the enlarged European Union (Oxford: Oxford University Press, 2006)

21 John Ruggie, 'Territoriality and beyond: problematizing modernity in international relations', International Organization 47, no. 1 (1993): 139-174.

22 Merje Kuus, Geopolitics and expertise: Knowledge and authority in European diplomacy (Chichester: Blackwell-Wiley, 2013), 29.

${ }^{23}$ Michael Loriaux, European Union and the deconstruction of the Rhineland frontier. (Cambridge: Cambridge University Press, 2008)

${ }^{24}$ Gearóid Ó Tuathail, Critical Geopolitics: The Politics of Writing Global Space (Minneapolis: University of Minnesota Press, 1996).

25 Veit Bachmann and James Sidaway, 'Zivilmacht Europa: a critical geopolitics of the European Union as a geopolitical power', Transactions of the Institute of British Geographers 34, no. 1 (2009): 94-109.; Ian Klinke, 'Postmodern geopolitics? The European Union eyes Russia', Europe-Asia Studies 64, no. 5 (2012): 929-947.; Merje Kuus, 'Policy and Geopolitics: Bounding Europe in EUrope', Annals of the Association of American Geographers 101, no. 5 (2011): 1140-1155.
} 
the Union's territoriality, ${ }^{26}$ the continued relevance of classical geopolitics in a number of member states ${ }^{27}$ and, more recently, the geopolitics of the Eurozone crisis. ${ }^{28}$

Within the literature on EU geopolitics particular attention has been given to the European Union's reordering of Eastern Europe through the policy of enlargement and the European Neighbourhood Policy (ENP). Whilst there have been a number of geographical expansions over the course of the EU's history, the 2004 incorporation of eight former Warsaw Pact states stands out as the most ambitious. Although it can hardly be read as an act of imposition or annexation, Behr, Böröcz and Walters have highlighted the neo-colonial overtones that reverberate through the EU's Eastern enlargement, particularly through the ideologically coloured aims of 'Europeanising', 'modernising' and 'liberalising' a space that was deemed economically and politically inferior. ${ }^{29}$ The unilateral adoption of the EU's acquis communautaire by new members and the Union's policy of conditionality belies the hierarchical geographies of core and periphery that characterise post-Cold War Europe. Whilst the Eastern enlargement group constitutes a cordon of semi-insiders, the neighbourhood group is one of semioutsiders. This is because the ENP tries to draw states into the orbit of the common market without the carrot of full membership. The very idea of a neighbourhood therefore also functions as a bordering practice that keeps certain states in an indefinite waiting room, at a friendly but neighbourly distance. ${ }^{30}$ Facing critiques of being a mere status quo policy, a more 'ambitious' ENP was re-launched in 2011.31 As will be argued below, academic knowledge funded by the Jean Monnet Programme has played a role in both enlargement and neighbourhood policies.

Political Geography and critical geopolitics have a long tradition of interrogating the conscription of academic knowledge to practices and narratives of statecraft. The starting point for these investigations is a Foucauldian conception of knowledge not as something outside but as laden with power. '[T]he exercise of power', he held, 'creates and causes to emerge new objects of knowledge and accumulates new bodies of information'. ${ }^{32}$ In response to this insight he famously suggested an archaeology of geographical knowledge ${ }^{33}$ to be written alongside a history of powers, 'from the great strategies of geo-politics to the little tactics of the habitat'. ${ }^{4}$ Political Geographers did not take this to mean that all forms of knowledge were similarly complicit in the

\footnotetext{
${ }^{26}$ Luiza Bialasiewicz, Stuart Elden and Joe Painter, 'The constitution of EU territory. Comparative European politics', 3, no. 3 (2005), 333-363.; Julian Clark and Alun Jones, 'The spatialities of Europeanisation: territory, government and power in Europe', Transactions of the Institute of British Geographers, 33, no. 3 (2008): 300 318.; Henk van Houtum, 'Human blacklisting: the global apartheid of the EU's external border regime', Environment and Planning D, 28, no. 6 (2010): 957-976.

27 Stefano Guzzini, The return of geopolitics in Europe? Social mechanisms and foreign policy identity crises (Cambridge: Cambridge University Press, 2012).

28 Ewald Engelen, Reijer Hendrikse, Virginie Mamadouh and James Sidaway, 'Turmoil in Euroland: the geopolitics of a suboptimal currency area?', Environment and Planning D, 29, no. 4 (2011): 571-583.; Alexander B. Murphy, 'Trapped in the Logic of the Modern State System? European Integration in the Wake of the Financial Crisis', Geopolitics 18, no. 3 (2013): 705-723.

${ }^{29}$ Hartmut Behr, 'The European Union in the legacies of imperial rule? EU accession politics viewed from a historical comparative perspective', European Journal of International Relations 13, no. 9 (2007): 239-262.; József Böröcz, 'East European entrants to the EU...diffidently yours', in The European's Burden: Global Imperialism and EU Expansion, ed. Salvatore Engel-Di Mauro (New York: Peter Lang) (2006): 153-164.; William Walters, 'The frontiers of the European Union: A geostrategic perspective', Geopolitics 9, no. 3 (2004): $674-698$.

${ }^{30}$ Luiza Bialasiewicz, 'The new political geographies of the European "neighbourhood"', Political Geography 28, no. 2 (2009): 79-89, 79.

31 European Commission, 'A new and ambitious neighbourhood policy', available at http://europa.eu/rapid/press-release IP-11-643 en.htm?locale=en (2011) [accessed 10 February 2014].

32 Michel Foucault, Power/Knowledge: Selected Interviews and Other Writings 1972-1977 (New York: Panthen Books, 1980), 51.

33 Ibid., 69.

34 Ibid., 149.
} 
exercise of geopolitics, but that all knowledge, perhaps especially state-funded projects like European Studies, should be contextualised and historicised.

In an attempt to complement Foucault's decentred and ultimately elusive conception of power with a focus on human agents, Political Geographers have turned to Antonio Gramsci and his theorisation of the intellectual. For Gramsci, intellectuals were famously not the autonomous, independent and objective figures presumed by the enlightenment, but political agents who produce knowledge for their social class. He saw these intellectuals as providing both the technical knowledge needed for a particular mode of production and as sustaining (and potentially altering) particular conceptions of the world that made up the ideological superstructure of their society. ${ }^{35}$ Political Geographers have reworked this concept into that of the 'intellectual of statecraft' to capture an elite of experts, advisors, think tankers and policy-makers, who speak authoritatively about geopolitics and who propagate knowledge that serves their social strata. ${ }^{36}$ In doing so, they have paid particular attention to the institutional sites and socio-economic structures that enables elite knowledge to be articulated. As Kuus reminds us, 'their practices are not homogeneous, nor are they necessarily accepted by the population at large' but rather 'establish the parameters of expertise and debate'. ${ }^{37}$ Moreover, in the context of Eastern Europe, such intellectuals should be understood as active agents who skilfully attracted Western attention and money by telling stories Westerners wanted to hear. ${ }^{38}$

European Studies can easily be grasped as providing students with the technical knowledge to work with EU legislation on the one hand, and the ideological motivation to become ambassadors of European integration on the other. These are precisely the types of intellectuals that can be encountered in the context of the Jean Monnet programme, academics with a purpose that extends beyond the immediate aims of intellectual curiosity. Their operation on the policy-academy nexus points to the geopolitics of area studies.

\section{The Jean Monnet Programme and the EU's Eastern project}

Launched in 1989, the Jean Monnet Programme has supported a wide range of academic activities in the field of European integration studies. These have included professorships, modules, research centres and more recently the ad personam chairs, designed to attract former high-level practitioners. As of 2007 the Jean Monnet has been integrated into the Commission's lifelong learning programme, which has promoted the European Union in schools (Comenius) through student exchanges (Erasmus) as well as vocational (Leonardo) and adult education (Grundtvig). Whilst initially designed to fund institutions throughout the European Communities, the Jean Monnet Programme was gradually enlarged to include potential new member states like Hungary and Poland (1993), the Czech Republic (1997) and in 2001 all other parts of the world. Reaching approximately 265,000 students every year, the programme's official aim has been 'to stimulate excellence in teaching, research, reflection and debate in European integration

\footnotetext{
35 Antonio Gramsci, Selections from the Prison Notebooks (New York: International Publishers, edited by Q. Hoare and G. Nowell Smith, 1971), 9.

36 Gearóid Ó Tuathail and John Agnew, 'Geopolitics and discourse: Practical geopolitical reasoning in American foreign policy', Political Geography 11, no. 2 (1992): 190-204, 193.

${ }^{37}$ Kuus, Geopolitics reframed, 14.

38 Ibid, 98.
} 
studies'. ${ }^{39}$ With an annual budget of 170 million Euros, it has set up 165 Jean Monnet Centres of Excellence, 879 Jean Monnet Chairs and 2,139 Jean Monnet Modules. ${ }^{40}$

Possibly in response to attacks from the Europhobe far right, the European Commission has emphasised that funding proposals to the Jean Monnet Programme are only assessed according to academic rather than political criteria. It has stressed that academics who receive funding are 'in no way restricted in their academic freedom' but 'encouraged to study the European Union in an independent and critical manner'. ${ }^{41}$ In an attempt to make the application process transparent, the Commission has made successful bids, waiting lists and even the assessment grid publicly accessible. Nevertheless, the exact criteria remain somewhat nebulous and the titles of successful projects would suggest an overwhelming majority of problem-solving and/or Europhile approaches. ${ }^{42}$ Understandably, some academics have in the past worried about the academic freedom and critical distance in European integration studies. At the 2009 Jean Monnet conference 'Twenty Years of Support for European Integration Studies: From the Jean Monnet Action to the Jean Monnet Programme' Helen Wallace raised questions of quality control and problematised the blurred border between analysis and advocacy in European integration studies. ${ }^{43}$ This warning seemed particularly pertinent given the speech of the Commissioner for Education, Training, Culture and Youth at the same event in which Jean Monnet professors were hailed as 'ambassadors of European integration in Members States, in the candidate countries, and around the world'.44 These words echoed the Commission's assessment that Jean Monnet funding had 'greatly contributed to the European Union's visibility in the world'. ${ }^{45}$ It is this global aspiration that requires further attention for it points to the scheme's geopolitical underpinning.

The most detailed discussion of the political rationale behind the Jean Monnet Programme has emerged from historians. Varsori, himself a Jean Monnet Professor, has traced the rise of the European Commission's financial support for historical research into European integration and concluded that the EU's financial commitment was formative to EU Studies during the 1990s. 'In the early period in particular' he has argued, 'academic selection criteria were not strictly applied', leading to 'strongly proEU attitudes'. ${ }^{46}$ Calligaro has gone back to the early 1980s to unpack the way the Commission was initially designed an information rather than a research policy. ${ }^{47}$ She shows how the Union actively encouraged deterritorialised and teleological histories of Europe whilst simultaneously worrying that by doing so it replicated the efforts of so-

39 European Commission, 'Jean Monnet Programme - key activity 1', available at http://eacea.ec.europa.eu/llp/funding/2013/call jean monnet action ka1 2013 en.php (2013) [accessed 4 February 2014].

40 European Commission, 'Jean Monnet Programme', available at http://eacea.ec.europa.eu/llp/jean monnet/jean monnet en.php (2013) [accessed 4 February 2014].

41 DG Education and Culture, 'Jean Monnet Chairs', available at http://ec.europa.eu/education/jeanmonnet/chairs_en.htm (2013) [accessed 4 February 2014].

42 The Commission's archive of Jean Monnet projects (1990-2012), at http://eacea.ec.europa.eu/llp/jeanmonnet/directory/New/Version/2008/V1/ajmrepertoire/distrib.Asp.

43 Helen Wallace, 'Political Science and the study of European integration', Jean Monnet Conference, Brussels, 7 September 2009, (2009) available at ec.europa.eu/education/jeanmonnet/doc/conf09/wallace_en.pdf [accessed 18 December 2013].

44 Ján Figel', 'Critical reflection and reliable information: the Jean Monnet community and the future course of the EU', Jean Monnet Conference, Brussels, 7 September 2009, (2009) available at ec.europa.eu/education/jean-monnet/doc/conf09/figel_en.pdf [accessed 21 December 2013].

45 DG Education and Culture, 'Jean Monnet: the European Union and the world - European success stories', available at ec.europa.eu/education/jean-monnet/doc/success2008 en.pdf(2008) [accessed 14 December 2013].

46 Antonio Varsori, 'From normative impetus to professionalization: origins and operation of research networks", in European Union History Themes and Debates, eds Wolfram Kaiser and Antonio Varsori (Basingstoke: Palgrave Macmillan, 2010): 6-25, 18.

${ }^{47}$ Oriane Calligaro, Negotiating Europe. The EU promotion of Europeanness since the 1950s (Basingstoke: Palgrave, 2013), 74. 
called 'totalitarian' states to rewrite history. ${ }^{48}$ Nevertheless, these otherwise very interesting studies have left unexplored the way in which the Jean Monnet Programme has not just been entangled in a particular rewriting of European time (history) but also in the redesign of European space (geopolitics). This transformation of European space through the Jean Monnet Programme is particularly visible in Eastern Europe, where it has played out in the dual policies of enlargement and neighbourhood. It can be traced in three realms, the geographical distribution of funds, the policy discourses surrounding the programme and the promotion of a particular type of academic, the intellectual of statecraft.
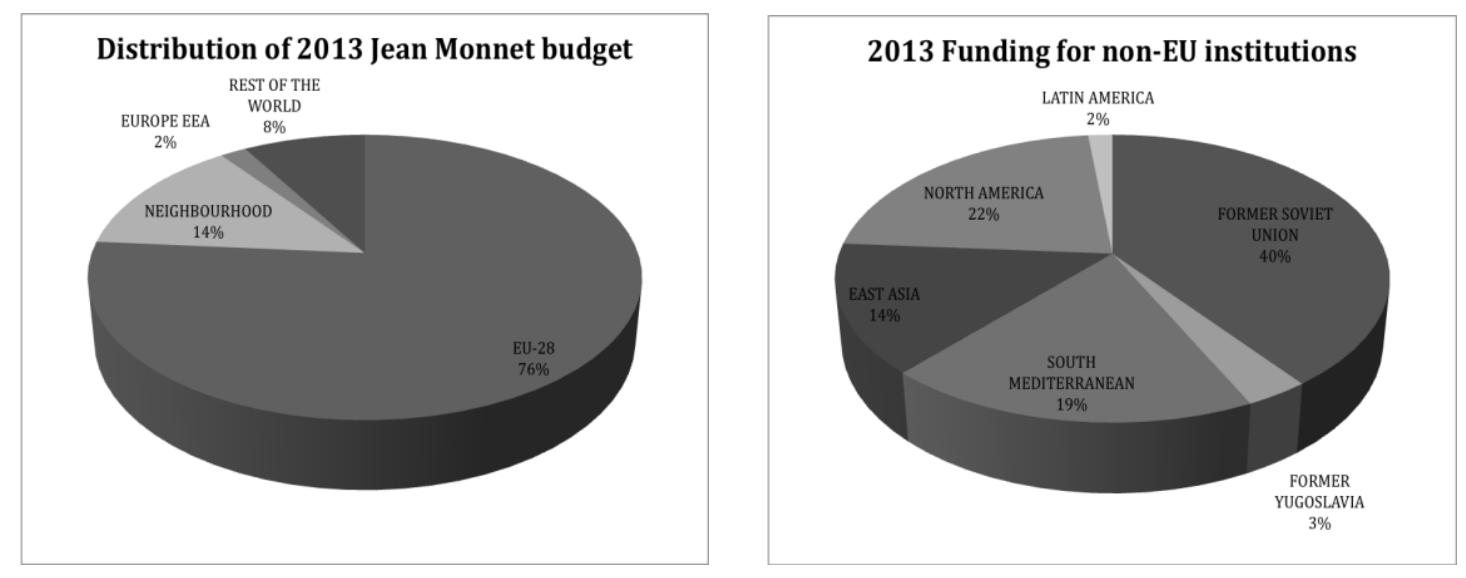

As stated above, the European Union has frequently emphasised the Jean Monnet's global aspirations and whilst the vast majority of funds continued to go to EU members, a significant $24 \%$ of the 2013 budget was given to non-EU institutions [figure 1]. Interestingly, the vast majority of this funding (62\%) was distributed not to North America, which has long boasted a strong culture of European Studies, but to states that either border the EU or are covered by the European Neighbourhood Policy [figure 2].49 This neighbourhood group includes the states of former Yugoslavia, the South Mediterranean (North Africa, the Middle East and Turkey) and the former Soviet Union. Out of these it is the latter group that receives by far the most significant share. Crucially, an examination of the distribution of chairs and modules over the last decade shows that the funding for this group increased significantly after the launch of the 2009 Eastern partnership and the revamping of the European Neighbourhood Policy in 2011 [figure 3].50

Moreover, such shifts in the geographical distribution are not limited to the European neighbourhood, but can also be observed in the more established politics of enlargement. This becomes most visible in the case of the 2004 enlargement round, which was largely, with the exception of Cyprus and Malta, an expansion to Europe's East. An analysis of the 2004 group for the period 1990-2013 shows a rise in successful bids before formal accession and a decrease in the aftermath, particularly in the case of Jean Monnet modules [figure 4]. Whilst this could be attributed to a spontaneous rise in interest in accession states, an alterative reading would emphasise that these shifts also correspond with the rise and fall of the European Union's enlargement agenda and the emergence of the neighbourhood policy.

\footnotetext{
48 Ibid, 45.

49 Data for figures 1 and 2 retrieved from the Commission's 2013 list of successful Jean Monnet projects, http://eacea.ec.europa.eu/llp/funding/2013/selection/selection_jean_monnet_ka1_2013_en.php

50 Data for figures 3 and 4 retrieved from the Commission's archive of Jean Monnet projects (1990-2012), at http://eacea.ec.europa.eu/llp/jeanmonnet/directory/New/Version/2008/V1/ajmrepertoire/distrib.Asp.
} 

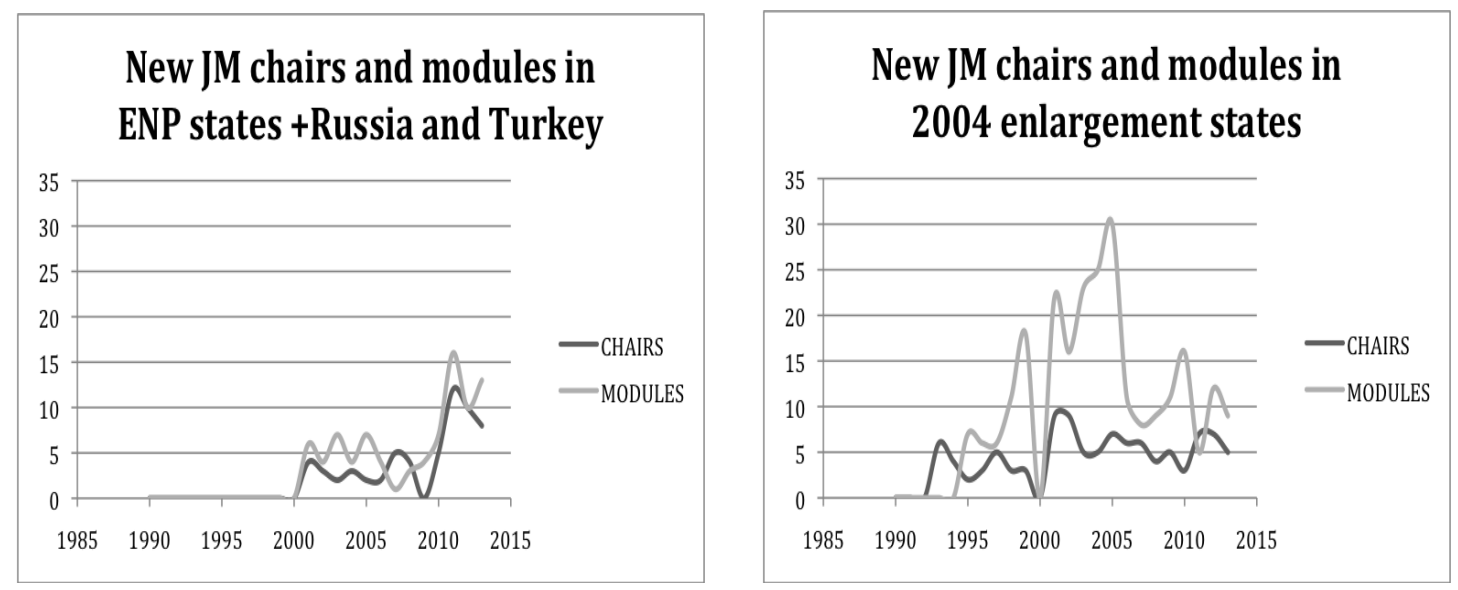

Interestingly, policy-makers in the European Commission have been surprisingly explicit about the imperatives behind these shifts. The Commission has long described the Jean Monnet Programme as a 'tool for EU accession'.51 Odile Quintin, then Director-General for Education and Culture, explained in 2009 that the Jean Monnet community had been 'a real actor for change' and had 'helped prepare central and eastern European countries for EU accession'.52 Concluding that the Jean Monnet Programme had 'a twin role as public diplomacy and global think-tank of the Union', she saw 'scope for a renewed role for the programme within the Neighbourhood Policy and the recently launched Eastern Partnership'. This stance has been echoed in the Brussels media, which has seen the programme's 'greatest impact in the enlargement of the EU'. This is because 'academics in accession countries received support from the programme, providing expert advice to their governments when negotiations began, training civil servants, and even going into politics themselves'. ${ }^{53}$ In this vein, Erhard Bussek, then Jean Monnet Chair ad personam at Salzburg University and former Special Coordinator of the Stability Pact for South Eastern Europe, promised in 2009 that the Jean Monnet Programme would help to alleviate the "weakness of the traditional systems' of Central, Eastern and South Eastern Europe. ${ }^{54}$ This framing of accession states as traditional and weak reinforces arguments about the EU's neo-colonial gaze upon its East.

As the European Commission has in the past proudly announced, several Jean Monnet professors have played 'an important role in the preparation of their countries for membership'. ${ }^{55}$ The list of these intellectuals is long, but a few high profile cases are worth singling out. Professor Saryusz-Wolski was supported by a Jean Monnet Fellowship before serving as the Vice-President of the European Parliament from 20042007. He played an important role in establishing the Warsaw campus of the College of Europe (Natolin) and his 'stubbornness' in negotiating Poland's accession agreement

51 European Commission, 'Jean Monnet conference 2009: 20 years of support for European integration studies' Brussels, 7-8 September 2009, available at http://ec.europa.eu/education/jeanmonnet/anniversary en.htm (2009) [accessed 20 December 2013].

52 Odile Quintin, '20 Years of Support for European Integration Studies: From the Jean Monnet Action to the Jean Monnet Programme', Jean Monnet Conference, Brussels, 8 September 2009, (2009) available at ec.europa.eu/education/jean-monnet/doc/conf09/quintin.pdf [accessed 15 December 2013], 6-7.

53 European Voice, 'It's time to get with the programme', (2009) available at http://www.europeanvoice.com/article/imported/it-s-time-to-get-with-the-programme-/66149.aspx [accessed 26 January 2014].

${ }^{54}$ Erhard Busek, 'Creating Europe: education, reconciliation, history', speech at Jean Monnet Conference in Brussels on 7 September 2009, available at ec.europa.eu/education/jean-monnet/doc/future/busek_en.pdf (2009) [accessed 15 December 2013].

55 DG Education and Culture, 2008, 5. 
has been called 'legendary' by the Brussels press. ${ }^{56}$ The Slovene Dimitrij Rupel served as Foreign Minister of his country after receiving funding through the Jean Monnet Programme. As European Voice writes in 2007, the 'committed anti-communist' was 'directly involved in most of the developments which turned Slovenia into a poster boy of European integration'.57 Currently a Jean Monnet chair at the Central European University, the Hungarian Péter Balázs served as a practitioner in a number of functions, including a brief spell as Commissioner for Regional Policy in the direct aftermath of Hungary's EU accession. Hungarian President at the time was another former Monnet man, a Conservative whose 'legal expertise greatly helped his country in overcoming problems arising from its new EU membership'. ${ }^{58}$ Another such intellectual on the interface between policy and the academy is Professor Siniša Rodin. The Commission has praised his team of lecturers at Zagreb University both for being members of the Croatian accession negotiating team and for playing a leading role in popularising the idea of European integration. ${ }^{59}$ It is crucial to note that whilst the funding received through the scheme might be relatively insignificant for the budgets of wealthier Western European institutions (chairs, centres and modules are funded up to a total grant of 45,000 Euros), the grants have a different weight and status for universities in Europe's East.

\section{European integration studies as area studies}

The examination of the geographical politics, policy imperatives and intellectuals characteristic of the Jean Monnet Programme has brought to light the close relationship between European integration studies and the policy objectives of the European Union. Jean Monnet academics have a dual role as ambassador and expert, a combination that points to the geopolitical underside of their endeavours. This is not necessarily surprising to those knowledgeable of the history of area studies. Inspired by Edward Said's observation that area studies favoured state-funded forms of orientalism, ${ }^{60}$ Political Geography has long pointed to the geopolitical underpinnings of area studies. Kuus has noted that area studies played an important role in preparing Eastern Europe for enlargement. ${ }^{61}$ Although she was referring here to East European Studies, the findings presented above seem to suggest that European integration studies has played a pivotal role in the EU's Eastern geopolitics, too.

Whilst the study of areas has its roots in the age of European exploration and practices of imperialism, it played its most significant role in the second half of the $20^{\text {th }}$ Century. After 1945, money was poured into the academic study of vital geopolitical regions, particularly the Soviet bloc and more recently into Middle Eastern Studies. In doing so, these funds have supported empirical knowledge that is easily digestible by policy-makers and area studies has had a tendency to tell stories that conform to the hegemonic geopolitical discourses that circulate in policy circles (Dalby, 1988, p. 426).62 This conformity to the demands of practitioners has been exacerbated by frequent shifts in geopolitical interest that have rendered area studies vulnerable to a drying up of

\footnotetext{
56 European 'Poice, positioner' (2005), available at http://www.europeanvoice.com/article/imported/pole-positioner/52100.aspx [accessed 18 January 2014].

57 European $\quad$ Voice, 'The diplomat', (2007) available at

http://www.europeanvoice.com/article/imported/the-diplomat/58888.aspx

${ }^{58}$ Guardian, 'Ferenc Mádl obituary', available at http://www.theguardian.com/world/2011/jun/15/ferencmadl-obituary (2011) [accessed 26 January 2014].

59 DG Education and Culture, 2008, 22.

60 Edward Said, Orientalism (London: Penguin, 1978), 26.

61 Merje Kuus, 'Europe's eastern expansion and the reinscription of otherness in East-Central Europe', Progress in Human Geography 28, no. 4 (2004): 472-89, 475.

62 Simon Dalby, 'The Soviet Union as Other', Alternatives 13 (1988) 415-442.
} 
funds and in constant need of proving its strategic importance to bureaucratic funding bodies. It has been uncommon to approach European Studies as a form of area studies, both because area studies has traditionally been associated with the study of distant 'Other' cultures and because European Studies has often sold itself as a Political Science, sometimes subdivided into Politics, Comparative Politics, International Relations and Public Administration.63 As Cini has noted however, European Studies still resembles area studies. ${ }^{64}$ In many ways, it would be more precise to argue that European Studies most closely resembles the enfant terrible of area studies: Cold War era Sovietology.

Sovietology emerged after 1945 when demand for the research and teaching into the Soviet Union exploded throughout the newly created North Atlantic community. Notorious today for its heavy state funding and its inability to predict the crisis of Soviet power, it played an important role in providing intellectual legitimacy for the Cold War. ${ }^{65}$ Like the Europeanists who are funded through the Jean Monnet Programme today, Anglo-American Sovietologists operated on the interface of policy and academy and attracted a vocationally oriented student body. Many leading US Cold Warriors had a background in Sovietology, including such luminaries as George F. Kennan, Zbiginiew Brzezinski, or Condoleezza Rice. Moreover, like European Studies, Sovietology was an interdisciplinary field that combined fields like Political Science, Economics, History and Sociology whilst simultaneously emphasising the promotion of language skills. It too was preoccupied with the analysis of formal political institutions and could rely on close financial ties with state bureaucracy. In the same way as European Studies is committed to the grand narrative of European integration today, Sovietology was conscripted to a particular political storyline: Soviet totalitarianism. Admittedly, the totalitarianism narrative was not left unchallenged in the later stages of the Cold War, ${ }^{66}$ but like European Studies, this did not happen to the degree that a true intellectual heterodoxy would emerge. Much like European Studies, Sovietology was resilient to larger theoretical developments and lacked a through self-reflective turn. Perhaps most importantly, it was as dependent on the continued existence of its object of study as European Studies is today. When the USSR disappeared, departments were closed and journals renamed. As the geopolitical gaze moved elsewhere, Sovietologists either had to turn to different geographical regions or to the study of post-Communist 'transitions'. Rather than telling the story of historical repetition, they had to tell the tale of European progress. In doing so, however, they were soon joined by a growing body of work that studied 'Europeanisation' in Eastern Europe and which was located in the field of European Studies.

In this sense it could be argued that European Studies and its narratives of spillover and historical progress partially filled the vacuum left after the demise of Sovietology, an insight that allows a return to Ryner's puzzle as to why the recent Eurozone crisis took European Studies by surprise. ${ }^{67}$ It is perhaps not simply that European Studies has been too mesmerized by teleological readings of European integration and too preoccupied with EU institutions that it has been inattentive towards the dynamics of European (and global) crisis capitalism. This is true, but there seems to be another problem here that European Studies shares with Sovietology. After

\footnotetext{
63 Mads Dagnis Jensen and Peter Marcus Kristensen, 'The elephant in the room: mapping the latent communication pattern in European Union studies', Journal of European Public Policy 20, no. 1 (2013): 1-20. ${ }^{64}$ Michelle Cini, 'The "state of the art" in EU Studies: from politics to interdisciplinarity (and back again)', Politics 26, no. 1 (2006): 38-46, 44.

65 Michael Cox, 'Why did we get the end of the Cold War wrong?', The British Journal of Politics and International Relations 11, no. 2 (2009): 161-176.; Richard Sakwa, 'Once again through the looking glass (darkly)?', Review of International Studies 25, no. 4 (1999): 709-719.

66 David Engerman, Know your enemy: The rise and fall of America's Soviet experts (Oxford: Oxford University Press, 2009), 286.

67 Ryner, 649.
} 
all, both fields are unusual forms of area studies in that they target both a geographical area and a particular polity (the Soviet Union and European Union). Crucially, the dependence of Sovietology on the continued relevance of its object of study culminated in a situation in which Sovietologists 'could never imagine a world without the Soviet Union, a world without themselves' ${ }^{68}$ Similarly, in order to understand the dynamics of European crisis and the forces of disintegration, Europeanists would have to imagine the demise of their own academic identity. A world without the European Union, after all, might not require the field of European integration studies, apart from a few historians perhaps.

\section{Conclusion}

This article has sought to pose questions about the political context in which knowledge on European integration is produced. In doing so, it has tried to shed light on the way funding through the Jean Monnet Programme has correlated with the European Union's geopolitical designs for Eastern Europe. However, rather than the backbone of an omnipotent propaganda machine, the scheme is only one agent of a fundamental blurring between theory and practice in European Studies. Funding for the field in Eastern Europe has operated as part of the Union's soft power and has helped to pave the way for a politics of Europeanisation. Of course, practitioners do not simply plug political messages into the academy, which then indoctrinates its students, who are in turn assimilated into the Brussels elites. The story is messier and includes crossfertilisation, inefficiencies and political doubts on all levels. Nevertheless, there does exist a surprising intellectual homogeneity in European Studies that is marked by a combination of think tankish theorisations, vocational teaching and policy-relevant writing. The article has suggested that the belatedness of the critical turn in European Studies may have its roots in the particular policy-academy nexus integral to the study of areas.

Area studies has a long tradition of speaking truth for rather than to power, but rarely has this been so transparent as in the case of European Studies and its object of study, the European Union. Whilst Anglo-American Sovietology experienced similar forms of state engagement during the Cold War, it is noteworthy that the North Atlantic Treaty Organization did not fund a scheme of 'Dwight D. Eisenhower chairs'69 to promote the study of Soviet totalitarianism (although it does provide funding through its 'Science for Peace and Security' Programme). Fields like Political Geography, International Political Economy and lately even International Relations have been much more remote from state influence and have, possibly because of this, cultivated more critical research on European integration. What is particularly problematic about the policy-academy nexus in European Studies is the latter's intimate involvement in what Walters and Haahr call the governmentality of Europe. ${ }^{70}$ Whereas graduates of European Studies might rarely penetrate the upper echelons of the Brussels bureaucratic apparatus, they are familiarised with the Union's governing rationalities and techniques. Jean Monnet Professors moreover, especially in the field of EU law, are often directly involved in this art of governing Europe, thereby subverting the university's traditional purpose. The promotion of intellectual curiosity, complex understandings and critical inquiry are replaced by an instrumental logic that foregrounds vocational and policy goals.

\footnotetext{
${ }^{68}$ Michael Burawoy, 'The end of Sovietology and the renaissance of modernization theory', Contemporary Sociology 21, no. 6 (1992): 774-785, 774.

69 Varsori, 6.

70 Walters and Haahr, Governing Europe.
} 
Further research is needed to tease out why the European Commission chose to enlist academics in its policy of Eastern enlargement. Perhaps there was a deeper understanding in Brussels of the role that public intellectuals had played in the destabilisation of Soviet Communism in the 1980s and the expansion of the Jean Monnet Programme is an attempt to create a similar dynamic. Alternatively, the Commission has simply been looking to fund the types of agents that have always played a leading role in European integration: technocrats. Much recent literature on European integration that is written from a critical perspective tends to construct the Union as a smooth machine, focusing on the overpowering alliance of capital, neoliberal ideology and state bureaucracy. In this light, it would seem that the policy-academy nexus characteristic of European Studies would be difficult to disturb. Yet, the fusion of state and university might not be as resilient as it seems at present.

The story of Sovietology reminds us that the demise of state funding for area studies departments and institutes can come rather suddenly and fundamentally disrupt academic communities when it does. Given the recent Eurozone crisis, European Studies would do well to theorise the politics of crisis and the possibility of European disintegration. This should not so much be a task of predictive theorisation, for crystal ball vision has long been at the centre of think tankish writing, but a move to nonteleological concepts and a more thorough disciplinary grounding. It should also consider its own academic vulnerability, specifically its dependence on the continued existence of its object of study. Unfortunately, the particular policy-academy nexus characteristic of area studies more generally is likely to impose limits on this endeavour. Although the colonisation of European Studies by EU Studies was hardly inevitable, the geopolitical reflex might be a little too enshrined in the very idea of an area, in the making and naming of a 'European' Studies, for the field to liberate itself from this conscription. ${ }^{71}$ Moreover, in order to leave the backwater of area studies, European Studies would have to emancipate itself from its current policy-academy nexus and find funds elsewhere. For the time being, the Jean Monnet Programme remains a bit of an elephant in the room. As a debate on the entanglement of European Studies with its object of study is only starting to emerge, it will be interesting to see whether European Studies starts to bite the hand that feeds it.

71 Tessa Morris-Suzuki, 'Anti-Area Studies', Communal/Plural 8, no. 1 (2000): 9-23, ADD AUTHOR REFERENCE. 